\title{
Peran Roh Kudus dalam Misi Allah:
}

\section{Ajaran yang Terlewatkan dalam Narasi Kisah Rasul 16:11}

\author{
Robby I. Chandra
}

\begin{abstract}
Abstrak
Tulisan ini meneliti ajaran yang tersembunyi dalam narasi mengenai respon terhadap penglihatan Rasul Paulus dalam Kisah Rasul 16. Pendekatannya adalah interpretasi narasi. Sebagai hasilnya, Kisah Para Rasul 16 mengajarkan pertama, kedaulatan Roh Kudus yang mendorong pemimpin-pemimpin yang dipilihnya melintasi batas-batas pandangan mereka dan kedua, mengenai peran-Nya mengajarkan agar kepemimpinan bersama perlu diterapkan di dalam proses melaksanakan Misi Allah.

Kata kunci: Roh Kudus, Missio Dei, Kepemimpinan, Transformasi, Gereja, interpretasi naratif
\end{abstract}

\begin{abstract}
The studi analyses the unrecognized teaching of the narratives in Acts chapter 16 concerning the response to the vision of St. Paul. The method used is narrative interpretation. As the results, Acts 16 teaches about both the role of the Holy Spirit to bring the chosen leaders to cross their boundaries as well as to teach them to practice Shared-Leadership in Missio Dei process.

Keywords: Holy Spirit, Missio Dei, Leadership, Transformation, Church, narrative intrepretation
\end{abstract}

\section{Pendahuluan}

Dalam dekade ini, percakapan mengenai Missional Church atau Gereja yang misional sudah ramai di berbagai belahan dunia. Gereja misional adalah Gereja yang secara utuh mengupayakan pelaksanaan misi Allah sehingga misiologinya tidak hanya dikaitkan dengan Kristologi atau teologi keselamatan, tapi juga dengan Pneumatologi atau teologi mengenai Roh Kudus dan Misi Allah Tritunggal dengan ciptaan-Nya. Di pertengahan tahun 2020 saja, dalam Academia.edu tersedia 4598 makalah mengenai topik itu. ${ }^{108}$ Misalnya, Desmond Soh, seorang yang melayani secara mandiri sebagai Misionaris di

${ }^{108} \mathrm{https}: / /$ www.academia.edu/search?utf8=\%E2\%9C\%93\&q=missional+church diunduh 28 Agustus 2020 
Indonesia dan juga merupakan pengajar dari Singapore Bible College menunjukkan bahwa, pembedaan antara Missio Dei atau Misi Allah dan Misi Gereja mulai diperjelas. Soh mencatat bahwa, misi Gereja seringkali merupakan program gerejawi yang mengutamakan kerangka teologi "keselamatan.” Dalam Misi Allah, Allah Bapa yang menjadi pengutus, dan Putra yang diutus untuk menebus umat manusia yang sudah jatuh dalam dosa sedangkan Roh Kudus diutus keduanya. Seperti diungkapkan oleh Karkkainen, ${ }^{109}$ Soh juga menyatakan bahwa, misi Allah tersebut sudah mulai sejak penciptaan langit dan bumi. Dengan demikian misi Gereja adalah bagian dari Misi Allah. ${ }^{110}$

Cornelius Johannes Niemandt dari University Pretoria, Afrika Selatan juga mengikuti kerangka pikir tersebut dan mencatat bahwa, dalam konsep Missio Dei ini diintegrasikan konsep kepemimpinan dan spiritualitas serta Missiologi. Ide dasarnya menunjukkan bahwa, misi ini adalah misi Allah dan gereja mengambil bagian di dalamnya yang berarti Gereja melakukan perjalanan spiritual dan spiritualitas yang mencari hikmat-Nya. Inilah yang dikenal dalam "langkah pertama dalam misi."111 Selanjutnya, dengan tegas Niemandt menyatakan bahwa, gereja hanya dapat ambil bagian di dalam Misi Allah bila memiliki kepemimpinan yang misional. Arti istilah kepemimpinan misional adalah kepemimpinan yang menekankan transformasi manusia dan lembaga agar berpartisipasi melalui hubungan akrab dan terus menerus berada dalam kuasa Roh Kudus. ${ }^{112}$

Jadi, inti dari misi yang Gereja kerjakan kini harus dimulai dengan integrasi landasan spiritualitas dengan kepemimpinan Gereja serta proses transformasinya. Apalagi dalam dunia kini yang sangat penuh disrupsi. Konsekuensinya, dalam konsep ini sangat ditekankan pentingnya kepekaan para pemimpin Gereja pada pimpinan Roh Kudus untuk melaksanakan transformasi yang berarti transformasi diri dan orang yang berjalan bersamanya.

\footnotetext{
109 Veli Matti Kärkkäinen, "Mission in Pentecostal Theology," International Review of Mission 107, no. 1 (June 1, 2018): 5-22, https://doi.org/10.1111/irom.12205.

110 Seng Chai Desmond Soh, "The Holy Spirit and Missions," in Holy Spirit: Unfinished Agenda, 2014, 26-28, https://www.academia.edu/35006499/Holy_Spirit_Unfinished_Agenda.

${ }^{111}$ Cornelius Johannes Petrus Niemandt, "Discerning Spirituality for Missional Leaders," in Contributions to Management Science, 2019, 151-68, https://doi.org/10.1007/978-3-319-98884-9_10. p. 155

112 Niemandt., p. 151.
} 
Konsep ini juga merupakan kelanjutan apa yang disebut oleh Karkkainen sebagai "Renaissance dalam Pneumatologi."113 Memang sebelum percakapan mengenai Misi Allah dan Misi Gereja ramai, secara berangsur-angsur telah terjadi perubahan besar di semua kalangan Kristen yaitu peningkatan kesadaran untuk meneliti dan membahas mengenai Roh Kudus secara lebih mendalam dan utuh, terutama di kalangan gereja arus utama dan Injili. Di kalangan Injili misalnya karya Francis Chan mengingatkan diabaikannya Roh Kudus yang adalah Allah kita di dalam teologi seperti yang ia nyatakan dalam bukunya Forgotten God: Reversing Our Tragic Neglect of the Holy Spirit:

I am convinced there is a desperate need in the church for the Holy Spirit of God to be given room to have His way. I think we can agree that there is a problem in our churches, that something is wrong. But I don't think we can reach an agreement on what to do about it. Most people do not connect what is missing or wrong with a particular need for the Holy Spirit. ${ }^{115}$

Hal ini berlanjut sampai kini, misalnya terbaca dari artikel Jimmy Evans dari the Liberty Baptis Theological Seminary. ${ }^{116}$

Sedikit banyak percakapan yang ramai mengenai Missio Dei dan Roh Kudus dipengaruhi kenyataan yaitu merebaknya Gerakan Pentakosta, Karismatik, Karismatik Baru, dan Apostolik Global terutama di belahan dunia selatan yang sangat menekankan pengalaman jemaat dengan Roh Kudus. Hal ini merupakan sumbangsih mereka pada Kekristenan sedunia.

Bila Misi Allah dikaitkan dengan peran Roh Kudus dan perlu terjadi transformasi sebagai dampaknya, baik di tengah jemaat dan dunia maka terutama pemimpin gerejawi juga perlu mengalami transformasi. Dua pertanyaan muncul dalam kaitan dengan pandanganpandangan di atas. Pertama, apakah cara untuk menumbuhkan kepemimpinan dengan kualitas seperti itu, yaitu yang mengalami hidup berpusat pada Roh Kudus dan mengalami proses transformasi sehingga menjadi pemimpin yang missional? Kedua, sejauh mana di dekade terakhir ini pneumatologi mendapat tempat yang sangat besar dalam kaitan dengan Gereja misional di Indonesia?

\footnotetext{
113 "Pneumatology: The Holy Spirit in Ecumenical, International, and Contextual Perspective," Choice Reviews Online 40, no. 04 (December 1, 2002): 40-2114-40-2114, https://doi.org/10.5860/choice.40-2114.

${ }^{115}$ Francis Chan, Forgotten God: Reversing Our Tragic Neglect of the Holy Spirit (Colorado Springs, CO: David C Cook, 2009). Chapter 1

116 Jimmie Evans, "The Third Person of the Trinity: How the Holy Spirit Facilitates Man's Walk with God," Fidei et Veritatis: The Liberty University Journal of Graduate Research 1, no. 1 (January 20, 2016), https://digitalcommons.liberty.edu/fidei_et_veritatis/voll/iss1/8.
} 
Alasan tulisan ini muncul adalah pengamatan pada gejala-gejala yang kentara terus menerus hadir di dalam berbagai gereja di Indonesia terutama pada gereja yang sangat mengakrabi Roh Kudus. Sebagian besar gereja dari kalangan ini misalnya, GPdI atau GBI yang merupakan kelompok terbesar kerap dipimpin oleh seorang pemimpin tunggal yang dipandang memiliki karisma yang luar biasa namun, sering juga mengalami perpecahan terus menerus terjadi antara lain karena sang pemimpin, sedangkan di pihak lain, sebenarnya mereka juga yang berupaya mencegah perpecahan yang parah seperti didatakan oleh Chang-Yai Hoon. ${ }^{117}$ Hal ini lebih nyata juga di negara lain di belahan bumi selatan. Di berbagai tempat bahkan, kepemimpinan karismatis ini dipandang harus dilanjutkan di dalam suksesi keluarga. Gejala lain adalah otonomi lokal atau gereja setempat sangat ditekankan dan perpisahan antar pemimpin mungkin dianggap kewajaran yang disebabkan oleh suasana egalitarian. ${ }^{118}$ Namun, belum ada penelitian bagaimana cara agar kepemimpinan yang transformasional dan misional dihadirkan. Sebagai catatan dapat pula dipertanyakan: apakah gejala di atas merupakan suatu hal yang dipengaruhi oleh kondisi budaya dan sosial lebih daripada pada pemahaman Alkitab yang tidak sempurna?.

\section{Metodologi}

Dalam kaitan dengan kedua pertanyaan ini, sebuah narasi yaitu Kisah Rasul 16 dijadikan titik berangkat pembahasan untuk memberikan pencerahan. Kajian yang dilakukan pada teks tersebut adalah metodologi kualitatif yaitu, interpretasi naratif yang termasuk dalam narratology.

Penggunaan metode interpretasi narasi didasarkan pandangan bahwa manusia menjalani pengalaman hidupnya sebagai pribadi dan komunitas dengan narasi. Kehidupan adalah narasi yang dihidupi. Artinya, orang membentuk hidup sehari-harinya berdasarkan narasi-narasi mengenai siapa diri mereka dan siapa orang lain sebagaimana dinarasikan. Narasi adalah gerbang melalui mana seseorang memasuki dunia di mana pengalamannya di dunia itu ditafsirkan dan dimaknai. ${ }^{119}$ Suatu metode narasi menerima

\footnotetext{
${ }^{117}$ Chang-Yau Hoon, “2. Pentecostal Megachurches in Jakarta: Class, Local, and Global Dynamics,” in Pentecostal Megachurches in Southeast Asia, Singapor: ISEAS-Yusof Ishak Institute Singapore, 2019), 21-46, https://doi.org/10.1355/9789814786898-005.p. 29

${ }^{118}$ Hendarto Supatra, "Mengenal Pentakostalisme Di Indonesia,” Jurnal Abdiel 3, no. 2 (November 22, 2019): 11-24, https://doi.org/10.37368/ja.v3i2.97.

${ }^{119}$ D. Jean Clandinin, Engaging in Narrative Inquiry, Engaging in Narrative Inquiry, New York: Routledge,
} 
gagasan bahwa suatu pemahaman dapat tersimpan di dalam suatu narasi yang disampaikan, disimpan, dan digali kembali. ${ }^{120}$

Isu yang harus dijawab adalah menyangkut objektivitas dalam proses kajian suatu narasi, apalagi narasi dalam teks Alkitab. Tulisan Catherine Riessman dapat dijadikan titik berangkat untuk menjaga objektivitas tersebut khususnya ketika ia memaparkan beberapa hal utama

a) Narasi menolong pribadi-pribadi memaknai pengalaman masa lalunya.

b) Narator menyakinkan dengan cerita-cerita,

c) Dalam konteks komunikasi lisa, digunakan berbagai cara untuk menyakinkan secara persuasif agar orang memandangnya sebagai kebenaran,

d) Dalam narasi dibuat para penerimanya terlibat dengan narator,

e) Ada hiburan,

f) Dapat juga narasi dibuat untuk mengarahkan pendengar atau pembaca ke tempat yang salah.

g) Suatu narasi dapat mendorong pendengar ke arah suatu perubahan nyata. ${ }^{121}$

Dengan menggunakan pedoman di atas, maka Kisah Rasul 16 akan dikaji sebagai suatu narasi yang memberikan pendengar dan penerimanya suatu pemaknaan, pedoman, dan arah bahkan dorongan nyata untuk bertindak. Karena itu tulisan ini meneliti:

1. Di dalam teks Kisah Rasul 16 ini, seperti apakah kaitan antara narasi ini dengan narasi dari seluruh kitab Kisah Rasul sebagai kerangka besarnya?

2. Siapakah pemeran-pemeran di dalam narasi?

3. Apakah yang dilakukan tiap pemeran?

4. Bagaimana kaitan antara pemeran?

5. Apakah suasana, gerakan, atau ritme yang muncul dalam narasi ini?

6. Apakah pemahaman, pemaknaan, pedoman, dan arah yang disampaikan pada komunitas pendengar melalui teks ini sebagai narasi?

\footnotetext{
2016, https://doi.org/10.4324/9781315429618. D. Clandinin, Handbook of Narrative Inquiry: Mapping a Methodology, San Francisco: Jossey-Bass, 2012, https://doi.org/10.4135/9781452226552.p. 98-115

${ }^{120}$ Ronald E. Fry, Appreciative Inquiry and Organizational Transformation: Reports from the Field. Westport, CB: Quorum Books, 2002., p. 166.

${ }^{121}$ Catherine Reissman, Narrative Analysis, Newbury Park, California: Sage, 1993
} 


\section{Temuan dari studi}

\section{Narasi Kisah Rasul 16 dalam Kerangka Narasi Besar}

Dalam Perjanjian Baru, tiga arus besar tulisan mengenai Roh Kudus dapat ditemukan di dalam kitab Injil Yohanes, Injil Lukas dan Kitab Kisah Para Rasul, serta tulisan-tulisan Paulus. Dalam Injil Lukas dan Kisah Rasul, peran utama dari Roh Kudus yang dipaparkan adalah sebagai pemberi kuasa pada para pemimpin dan orang yang melayani dalam melaksanakan misi penyampaian kabar baik. Hal ini telah memperkokoh kebiasaan kepemimpinan dan praktek hidup gereja termasuk gereja di Indonesia. Namun, ajaran atau pemahaman mengenai peran Roh Kudus di dalam Kisah Rasul pasal 16 ternyata berbeda dari paparan-paparan sebelumnya.

Kisah Rasul pasal 16 adalah bagian dari paparan mengenai perjalanan Paulus yang kedua untuk mengunjungi Gereja-gereja yang didirikannya. Bersama Injil Lukas, Kisah Rasul yang merupakan karya Lukas ini memiliki beberapa kekhasan. ${ }^{122}$ Mulanya tekanan penulis dalam kedua tulisan tersebut mengenai Roh Kudus dan perannya menjadi debat di antara para pakar, namun perpaduan pendekatan Narrative Criticism dan studi latar belakang menolong menghasilkan konsensus. ${ }^{123}$

Christopher Donlon menunjukkan bahwa, dalam kitab Kisah Rasul, Istilah Roh Kudus (pneuma) memang muncul 54 kali secara spesifik di dalam kitab Kisah Rasul. ${ }^{124}$ Hal ini dikaitkan dengan Lukas yang sangat menekankan kedatangan Allah dalam diri Kristus, kegiatan Roh Kudus dalam restorasi umat pilihan Tuhan, dan akhirnya, kerajaaan Allah dalam dalam hidup dan misi komunitas yang diberdayakan Roh Kudus. ${ }^{125}$ Injil Lukas menyentuh harapan bangsa Yahudi untuk pemulihan umat Tuhan, karena setelah mereka kembali dari pembuangan ke Babilonia, sebenarnya mereka masih terikat oleh banyak hal. Apalagi penjajahan Imperium Roma sangat nyata. Namun jawaban Lukas

\footnotetext{
122 Helena Martins, "Novel Metaphor and Conceptual Stability," in DELTA Documentacao de Estudos Em Linguistica Teorica e Aplicada, 2006, https://doi.org/10.1590/s0102-44502006000300010.

123 Jerry Camery-Hoggatt, "George K. A. Bonnah, The Holy Spirit: A Narrative Factor in the Acts of the Apostles," Pneuma 32, no. 3 (November 12, 2010): 438-39, https://doi.org/10.1163/157007410x533996.

${ }^{124}$ Christopher Donlon, “Luke's Pneumatological Eschatology: Theological Motifs in Luke-Acts” (unpublished paper, South Eastern University, 2012), https://www.academia.edu/2536151/Lukes_Pneumatological_Eschatology_Theological_Motifs_in_Luke_Acts. ${ }^{125}$ Donlon.
} 
mengejutkan karena, pemulihan itu datang berupa kehadiran diri Allah sendiri yaitu dalam diri Kristus.

Dengan demikian Kisah Rasul berada dalam kerangka tersebut. Menurut Ngyuen Van Thanh, inisiatif Roh Kudus dalam kitab Injil Lukas dan Kisah Rasul menjadi warna utama teologi Lukas khususnya, ketika Lukas merentangkan lingkup pandangan mengenai pemulihan yang mencakup juga orang-orang yang bukan Yahudi. ${ }^{126}$ Mengenai peran Roh Kudus dinyatakan oleh penulis ini "Roh Kudus juga melayani sebagai wakil Allah untuk menerapkan dan untuk melegitimasi keinginan dan rencana penyelamatan Allah bagi orang kafir juga. Lukas menunjukkan bahwa pencurahan Roh nubuatan mengenai orang kafir bukan hanya memenuhi janji yang disampaikan Joel dan Yohanes Pembaptis tapi juga oleh dibuat oleh Kristus sendiri dan Allah Bapa."127

Bila orang Yahudi mengharapkan Mesias atau pemulihan bagi bangsa mereka yaitu umat pilihan Allah, Lukas menunjukkan bahwa, pemulihan itu berarti kehadiran Kerajaan Allah sebagai sesuatu yang Ia sendiri ingin hadirkan di muka bumi. Jadi ketika menyatakan ajaran mengenai Roh Kudus, dalam Kisah Rasul, Lukas lebih menekankan peran Roh Kudus dalam memberi kuasa atau pemberdayaan bagi kesaksian atau misi Allah (1:8; 2:33-36 etc) yang menerobos batas budaya dan etnis, jadi bukan hanya ditujukan pada bangsa Israel.

\section{Analisis Narasi dan interpretasi}

Kisah 16 memaparkan: Dalam perjalanan keliling dari kota ke kota Paulus dan Silas menyampaikan keputusan-keputusan yang diambil para rasul dan para penatua di Yerusalem dengan pesan, supaya jemaat-jemaat menurutinya. Demikianlah jemaat-jemaat diteguhkan dalam iman dan makin lama makin bertambah besar jumlahnya. Mereka melintasi tanah Frigia dan tanah Galatia, karena Roh Kudus mencegah mereka untuk memberitakan Injil di Asia. Dan setibanya di Misia mereka mencoba masuk ke daerah

\footnotetext{
126 Nguyen Van Thahn, "God and The Gentile Mission: A Lukan Theological and Missiological Agenda," Sapientia Logos 5, no. 2 (2013): 1-31, https://www.academia.edu/4182827/God_and_the_Gentile_Mission_A_Lukan_Theological_and_Missiological _Agenda.

${ }^{127}$ Van Thahn. p.30 "Luke shows that the outpouring of the Spirit of prophecy upon the Gentiles not only fulfills the promises made by Joel and John the Baptist, but also those made by Jesus himself and by the Father."
} 
Bitinia, tetapi Roh Yesus tidak mengizinkan mereka. Setelah melintasi Misia, mereka sampai di Troas.

Dalam menganalisis teks Kisah 16 sebagai narasi, maka pertanyaan terbesar yang akan dibahas adalah identifikasi pemeran-pemeran dalam narasi ini. Dalam perjalanan melakukan misi Allah kali ini, Paulus berjalan bersama Silas. Silas adalah seorang yang dapat mengajarkan Firman Allah. Ia adalah seorang Yahudi sehingga mempermudah akses ke sinagoge-sinagoge. (Kisah 6:9). Namun, Silas juga memiliki kewarganegaraan Romawi (Kisah 16:37) sehingga, peraturan negara akan memberikan banyak perlindungan baginya seperti bagi Paulus.

Dalam perjalanan mereka tiba di Derbe dan Lystra. Dicatat dalam Kisah 16;1 “Di situ ada seorang murid bernama Timotius, ibunya adalah seorang Yahudi dan telah menjadi percaya, sedangkan ayahnya seorang Yunani." Paulus mengajaknya bergabung dengan mereka. Namun, ia juga menyuruh Timotius disunatkan.

\section{1.a. Pemeran dalam Narasi}

Pertama, dalam narasi ini peran Paulus sangat besar. Ia yang terbeban melakukan perjalanan misi yang kedua untuk mengunjungi jemaat-jemaat yang didirikannya. Ia juga yang merekrut atau menentukan siapa yang akan dianggapnya tetap menemani dirinya, memilih siapa yang akan menemaninya, serta menolak siapa yang dianggapnya tidak layak.

Peranan yang dimainkan oleh Paulus adalah peran seorang pemimpin yang melakukan suatu misi. Peranan ini adalah peranan yang memiliki resiko karena ia berasal dari kalangan yang akan dihadapinya dan mendengarkan penyampaian berita Injil yang dibawanya. Peranan lainnya adalah ia menyiapkan kedua orang yang berjalan dengannya, hal ini ternyata dalam penyunatan Timotius.

Kedua, mengenai peran Silas dan Timotius terbaca mereka menuruti sepenuhnya inisiatif dan pilihan Paulus. Keduanya mengiringi Paulus dan tidak dijelakan apa yang terjadi.

Ketiga, apa yang mereka lakukan juga tidak banyak dipaparkan kecuali adanya daftar lokasi yang dikunjungi atau dilewati. Mereka berjalan melalui Phrygia dan Galatia. Namun, kemudian Roh Kudus melarang mereka untuk menyampaikan Injil di Asia. Mereka melanjutkan perjalanan untuk memasuki Bithynia, tetapi Roh Kudus tidak 
mengijinkan mereka menuju kesana. Maka mereka bertiga melewati Mysia sampai ke Troas.

\section{1.b. Lokasi dan pergerakan}

Lokasi yang didatangi oleh Paulus adalah Phrygia, Galatia, Proconsular Asia, Mysia, dan Bithynia sebelum mereka tiba di Troas. Dalam Kisah Rasul 16 hal ini digambarkan sekilas saja. Terbaca bahwa, tekanan narasi tidak diletakkan pada lokasi-lokasi yang dikunjungi namun lebih komitmen Paulus menyampaikan berita Injil dan memperkuat persekutuan orang-orang percaya yang dihasilkan dalam perjalanan misi yang pertamanya.

\section{1.c. Kejutan: Pemeran utama dan tindakannya}

Pada ayat 6, dipaparkan dengan gamblang walaupun singkat pemeran lain di narasi ini. Pemeran ini, Roh Kudus, sangat menentukan dan berkuasa. Ia mencegah. Juga di dalam ayat 7 disebutkan Roh Yesus tidak mengizinkan mereka. Paparan mengenai para pemeran sebelumnya di narasi ini, kini tidak mendapatkan perhatian lagi. Fokus diletakkan pada apa yang Roh Kudus lakukan.

Dua kata muncul mengenai apa yang Roh Kudus kerjakan pada saat itu: mencegah dan tidak mengizinkan. Dalam bahasa aslinya kata yang dipergunakan pada ayat 6 adalah $\boldsymbol{\kappa} \boldsymbol{\omega} \lambda \boldsymbol{v} \boldsymbol{\theta} \boldsymbol{\varepsilon} \boldsymbol{v} \boldsymbol{\tau} \boldsymbol{\varepsilon}$ yang akarnya ada pada kata kolazo yang berarti telah dicegah, dihalangi, atau dihentikan. ${ }^{128}$ Kemudian dalam ayat 7 muncul kata eiasen ( $\boldsymbol{\varepsilon} \mathbf{l} \boldsymbol{\alpha} \boldsymbol{\sigma} \boldsymbol{\varepsilon} \boldsymbol{v}$ ) yang berarti tidak memberikan ijin atau tidak membiarkan. ${ }^{129}$

\section{1.d. Alur dan tempo}

Bagaimana persisnya pencegahan Roh Kudus atau bagaimana mereka tidak diijinkan sama sekali tidak dideskripsikan. Seakan dalam narasi ini dengan sengaja ada ruang yang dikosongkan. Bila dianalogikan dengan pegelaran musik, maka sampai saat ini musik berjalan ringan, dan cepat serta lancar. Kini mendadak terjadi peningkatan intensitas melalui peran Roh Kudus yang mencegah dan menghalangi tim misi ini. Kemudian terjadilah jeda atau kesunyian tanpa kejelasan. Dalam suatu karya musik, jeda berfungsi untuk menyiapkan atau mengarahkan pendengar pada sesuatu yang penting. Dalam

\footnotetext{
128 (https://biblehub.com/interlinear/acts/16-6.htm

129 ( https://biblehub.com/greek/eiasen_1439.htm )
} 
suatu narasi, tempo atau ritme pemaparan juga memiliki fungsi yang sama. Jadi dalam narasi Kisah 16, maka jelas bahwa, hal ini disengaja untuk mengarahkan pembaca dan pendengar pada suatu hal yang signifikan.

Kemudian narasi berlanjut dengan keberadaan mereka di Troas. Sampai sejauh ini semua arah perjalanan dan maksud Paulus menjadi terintang. Namun, klimaks muncul dalam narasi ini. Di ayat 9 disebutkan, Pada malam harinya tampaklah oleh Paulus suatu penglihatan: ada seorang Makedonia berdiri di situ dan berseru kepadanya, katanya: 'Menyeberanglah ke mari dan tolonglah kami!'

Ayat ini dilanjutkan dengan narasi bahwa Setelah Paulus melihat penglihatan itu, segeralah kami mencari kesempatan untuk berangkat ke Makedonia, karena dari penglihatan itu kami menarik kesimpulan, bahwa Allah telah memanggil kami untuk memberitakan Injil kepada orang-orang di sana.

Mengenai penglihatan tersebut berbagai hal dapat ditelaah. Istilah penglihatan itu adalah ǒ $\rho \mu \alpha$ (horama) yang muncul 12 kali dalam Strong Greek. John MacArthur dalam buku One Faithful Life mencatat bahwa, hal ini merupakan penglihatan kedua dari keenam penglihatan yang dialami Paulus. ${ }^{130}$ Penglihatan ini tidak menunjukkan kehadiran malaikat atau mahluk surgawi namun manusia biasa.

Perlu dicatat bahwa di dalam Kisah 16 ini muncul dua istilah berturut-turut yaitu, Roh Kudus dan Roh Yesus. Hal sudah dibahas banyak tulisan. Intinya adalah Lukas menunjukkan Kristus adalah Roh yang mengintervensi hidup manusia seperti Roh Allah yang ada di Perjanjian Lama. Bahkan, Lukas menekankan bahwa kehadiran Roh Kudus dalam mereka yang sudah dibaptis di dalam-Nya akan kentara dan nyata di dalam hidup pribadi dan komunitas orang percaya. ${ }^{131}$ Namun, bagian yang menjadi fokus pada tulisan ini adalah respon mereka pada penglihatan yang diterima Paulus.

\section{1.e. Klimax: Pesan tersembunyi}

Di dalam ayat 10 untuk pertama kali muncul kata "kami." Bila sebelumnya narasi ini mirip suatu pelaporan, kali ini pelapor seakan menuliskan narasi ini karena, ia mengikuti

\footnotetext{
130 John MacArthur, Strange Fire: The Danger of Offending the Holy Spirit with Counterfeit Worship (Nashville, Tennessee: Neslon, 2013)., p.110

131 "Pneumatology: The Holy Spirit in Ecumenical, International, and Contextual Perspective," Choice Reviews Online 40, no. 04 (2002), https://doi.org/10.5860/choice.40-2114. p. 30
} 
dengan aktif di dalam apa yang dinarasikan. Warna narasi berubah dari sebuah catatan perjalanan atau peristiwa menjadi otobiografi atau jurnal perjalanan sang penulis. Ada para pakar menyatakan bahwa, di tempat ini Lukas, sang penulis ikut bergabung ke dalam tim misi Allah ini. Namun, ada pula yang menafirkan bahwa kata "kami" menekankan peranan saksi mata memberitakan apa yang benar terjadi karena, Injil Lukas dan Kisah Rasul ini memang ditujukan pada Theopilus atau orang-orang sejenisnya. Bahkan, ada pakar yang menunjukkan bahwa, bagian ini adalah serpihan dari tulisan orang lain yang kemudian dipersatukan ke dalam Kisah Rasul. ${ }^{132}$

Kembali pada struktur dan tempo dari narasi di Kisah 16 ini. Semua berjalan sangat cepat, dan beruntut aktivitas dimunculkan, lalu hadirlah kekosongan dan jeda. Namun, menarik sekali kata yang dimunculkan sebagai respon Silas, Timotius, dan Paulusa pada penglihatan tersebut. Kata yang dipergunakan dalah kata Yunani symbibazontes yang berarti menyimpulkan atau menyatukan nalar. Dalam Alkitab terjemahan bahasa Indonesia, istilah yang dipergunakan adalah menarik kesimpulan mengenai penglihatan diberikan kepada Paulus

Jeda atau kekosongan yang ditimbulkan narasi ini membuat pembaca atau pendengarkan mereningkan. Beberapa hal perlu ditafsirkan dari Kisah Rasul 16 dalam perjalanan pelaksanaan Misi Allah kedua ini.

Pertama, justru Paulus yang mendapatkan penglihatan tidak menafsirkan, menyimpulkan, atau memahaminya sendiri. Padahal sejauh ini peran dirinya sebagai pemimpin sangat menentukan. Kini, seluruh anggota tim misi ini bersama mencoba menarik kesimpulan. Peran Paulus sebagai pemimpin mereka, perekrut, pemrakarsa, pembangun gereja, dan orang yang mengalami berbagai resiko tidak membuatnya merasa berhak dan wajar memutuskan dan menafsirkan atau memaknai semua hal yang tidak biasa itu sendiri. Ia membuka ruang bagi Timotius dan Silas serta Lukas yang notabene adalah orang-orang baru untuk memaknai "sentuhan Roh Kudus." Apakah hal ini terjadi karena, rintangan dan halangan Roh Kudus menjadi pukulan bagi Paulus dan membebaninya dengan ketidakpastian dan pertanyaan-pertanyaan yang tidak terjawab, hal ini dapat menjadi spekulasi.

132 Matteo Crimella, “The Vision of the Macedonian: Acts 16:6-10,” Revue Biblique 2014, accessed August 30, 2020, https://www.academia.edu/39374935/The_Vision_of_the_Macedonian_Acts_16_6_10., p. 400 
Kedua, walaupun sudah ada jemaat-jemaat yang berdiri di Asia kecil, Roh Kudus yang bertindak sebagai pemeran utama dalam narasi ini menunjukkan bahwa, Paulus tidak diberikan keleluasaan memilih arah dan sasaran pekerjaan misinya. Wajarnya dalam perjalanan kedua ini, menyebarkan injil ke Asia kecil lebih lanjut sebagai suatu perkembangan masuk akal. Dalam narasi Kisah 16 jelaslah bahwa, peran Roh Kudus di sini adalah mendorong, menggiring, mencegah, dan kemudian membawa mereka ke tempat dan lokasi yang mungkin tidak terbayangkan sebelumnya. Roh Kudus juga berperan menentukan waktu atau jadwal pelayanan misional mereka. Jadi inisiatif Allah memang sangat kentara dalam teologi Lukas. Namun, pesan yang tersembunyi dalam Kisah 16 ini adalah peran kebersamaan manusia sebagai komunitas yang dipilih menjalankan misi Allah. Komunitas atau tim kecil dalam proses melaksanakan Misi Allah harus berperan untuk memaknai penglihatan atau pengarahan Roh Kudus. ${ }^{133}$

Ketiga, di tengah orang Yahudi yang masih menekankan etnosentrisme sebagai bangsa pilihan yang istimewa dengan keunggulan budaya disiplin dan nomistis, ternyata Roh Kudus menyeret mereka yang melaksanakan misinya menanggalkan hal tersebut. Mereka harus belajar bahwa Misi Allah menjangkau lebih luas dari lingkup internal bangsa pilihan-Nya. Sebenarnya, landasan pemahaman di atas muncul dari Pertemuan di Yerusalem (Kisah Rasul 15). ${ }^{134}$ Area geografis yang dijalani pun melebihi keinginan dan akal sehat tim misi Paulus. Dengan kata lain, dalam narasi ini ditekankan peran Roh Kudus mengajak mereka yang melaksanakan misi Allah untuk melangkah melintasi cakrawala iman, kejiwaan, hidup sosial, atau budaya mereka. Jadi Roh Kudus adalah Roh yang mengajar atau mendidik. Seorang yang sungguh mau melaksanakan misi Allah harus rela belajar, artinya menambah hal-hal baru dan membuang hal-hal baik yang sudah usang. Dengan demikian mereka yang sungguh menjadi pelaksana misi Allah bersedia diubahkan oleh Roh Kudus dalam ranah pemahaman iman, pola pandang tentang diri sendiri dan orang lain, serta hidup budaya dan sosial mereka. Dengan perubahan itu terbuka ruang yang besar dan Roh Kudus dapat mencurahkan kuasa-Nya dengan lebih leluasa.

\footnotetext{
${ }^{133}$ Crimella.p,403

134 David Peterson, "Additional Note: The Meaning and Application of the Council Narrative," in The Acts of the Apostles (Grand Rapids, Mich: Willliam Eerdsmans Pub, 2009), 442-446.
} 
Keempat, Roh Kudus mendidik mereka untuk mengenali rencana Allah dan menjadikannya sesuatu di atas rencana mereka. Tanpa menyeberang ke Macedonia, Injil mungkin hanya berhenti pada penduduk di Asia Minor atau Turki di masa kini. Di kemudian hari, dari Eropalah berbagai pelaksanan misi Allah bergerak ke seluruh dunia dengan hal-hal indah dan hal-hal gelap yang mereka bawa ketika budaya dan kepentingan ekonomi mereka dahulukan.

Kelima, seluruh Kitab Lukas dan Kisah Para Rasul juga sangat menekankan suatu ajaran: Basileia Tou Theo alias Kerajaan Allah. Kerajaan Allah adalah suatu suasana, keadaan, atau kondisi ketika kuasa, kemuliaan, keadilan, kekudusan, dan kasih-Nya dirasakan oleh manusia secara individu dan sebagai masyarakat bahkan seluruh umat manusia. Tepatnya, hidup yang sejati dianugerahkan-Nya. Perjalanan dan pelaksanaan misi Allah bukanlah membangun Israel baru dengan torat baru dan dinasti pemimpin-pemimpin tunggal yang baru. Kerajaan Allah adalah suasana yang dimulai dimana setiap orang, termasuk para pemimpin misional merasakan kehidupan baru di dalam-Nya. Kehadiran Roh Kudus di dalam roh, jiwa, dan badan dirasakan setiap hari.

\section{Pembahasan}

Setelah Gereja terpecah menjadi Gereja Barat dan Timur di tahun 1054, perkembangan pemahaman teologi mengenai Roh Kudus dan peran-Nya, khususnya di tengah mayoritas gereja Kristen di Barat tidak mendapatkan perhatian sebesar yang diletakkan atas Kristologi. Di dalam masa Reformasi, dalam doktrin Roh Kudus yang disusun oleh Martin Luther dengan menekankan peran Roh Kudus terutama pada hidup orang percaya dan keselamatan serta anugerah Allah. ${ }^{135}$ Selanjutnya, perhatian terbesar Gereja diletakkan pada pemahaman mengenai soteriologi, eklesiologi, dan mungkin Missiologi sementara Roh Kudus terlupakan. ${ }^{136}$ Karena itulah dua orang tokoh Gereja Orthodox timur, Vladimir

\footnotetext{
${ }^{135}$ Hans-Martin Barth, The Theology of Martin Luther, The Theology of Martin Luther, 2018, https://doi.org/10.2307/j.ctt22nm8rj.

136 Peter Zimmerling, "Pneumatology," in The Routledge Companion to Modern Christian Thought, 2013, https://doi.org/10.4324/9780203387856.
} 
Lossky dan Nikos Nissiotis menuding Gereja-gereja Barat sebagai menekankan Kristomonisme. ${ }^{137}$

Seorang penulis menyatakan di tahun 1957 Roh Kudus sering disebut sebagai Cinderella. ${ }^{138}$ Hal ini dipopulerkan oleh Jurgen Moltmann, seorang teolog yang menyatakan di tahun 1980 bahwa Gereja telah lama disebut mengabaikan Roh Kudus bahkan memperlakukan-Nya sebagai Cinderella di dalam teologi. Artinya, peran-Nya besar dan dampaknya dirasakan, namun perhatian yang diberikan pada peran dan lingkup pengaruh-Nya sangat terbatas. Moltmann juga yang kemudian mengembangkan pneumatologi yang menekankan peran Roh Kudus dalam proses penciptaan semesta sejak awalnya dan memberikan kehidupan. ${ }^{139}$

Pemahaman Moltman sangat mirip dengan warna Pneumatologi yang berkembang di gereja-gereja Orthodox Timur seperti dipaparkan dalam karya Anthon Thiselton yang sangat komprehensif. ${ }^{140}$ Yaitu, Roh Kudus sudah berperan sejak awal, di masa kini, dan di masa depan. Ia-lah Roh pemberi kehidupan, sesuai dengan pengakuan iman percaya Nicea-Konstantinopel.

Sementara itu, sejak awal abad 20, muncullah kalangan yang dikenal dengan nama gerakan Pentakostalisme. Asal usul gerakan dipandang berbeda-beda oleh para ahli. ${ }^{141}$ Di Amerika dipaparkan oleh Synan, Fox, dan Seymour, ${ }^{142}$ bahwa, gerakan ini dimulai di Topeka, Kansas namun menerima perhatian global ketika terjadi kebangunan rohani di Azusa Street pada tahun 1906. Walaupun mulanya hanya berada di kalangan sederhana dan di pinggiran, kekhasan gerakan ini nyata dalam memberi ruang sangat besar bagi perhatian pada Roh Kudus. Hal ini nyata dalam ibadah dan hidup orang percaya. Muncullah isu-isu yang diberi perhatian sangat besar seperti baptisan Roh, karuniakarunia Roh, penyembuhan ilahi, eksorsisme, dan berbagai hal di sekitarnya. Beberapa

\footnotetext{
${ }^{137}$ Hal ini dicatat pleh Veli-Matti Karkkainen, "The Ecumenical Potential of Pneumatology," Gregorianum 80, no. 1 (1999): 121-45, https://www.jstor.org/stable/23580447?seq=1., p.124

138 G. J. Sirks, "The Cinderella of Theology: The Doctrine of the Holy Spirit," Harvard Theological Review 50, no. 2 (1957): 77-89, https://doi.org/10.1017/S001781600002842X.

139 Jürgen Moltmann, The Spirit of Life: A Universal Affirmation (Minneapolis, Minnessota: Fortress Press, 2001)., p. 84

${ }^{140}$ Anthony Thiselton, The Holy Spirit: In Biblical Teaching, through the Centuries and Today (Grand Rapids: Michigan: Eerdmans, 2013)., p. 400

${ }^{141}$ Chang-Soung Lee, "Who Is the Father of Pentecostal Movement?," Journal of Youngsan Theology, 2018, https://doi.org/10.18804/jyt.2018.03.43.303.

${ }^{142}$ Lihat kajian David G. Roebuck, "Vinson Synan \& Charles R. Fox, Jr., William J. Seymour: Pioneer of the Azusa Street Revival (Alachua, FL: Bridge-Logos, 2012). 355 Pp., \$16.99 Paperback.,” Pneuma 35, no. 1 (2013), https://doi.org/10.1163/15700747-12341299.
} 
gelombang dan arus muncul di dalam gerakan ini misalnya, hadirnya kalangan Karismatis di tengah warga dan pimpinan Gereja Injili atau Arus utama. Di tahun 2000an muncullah gerakan yang dinamakan Neo-Charismatics yang mencakup 295 juta pengikut di dunia. ${ }^{143}$ Di kemudian hari muncullah nama Peter Wagner dengan gerakan Reformasi Apostolik Baru.

Gerakan-gerakan ini menekankan peranan Roh Kudus yang terutama menyentuh ranah emosi dalam hidup pribadi, keluarga, dan jemaat yang dapat menjadi dasar menyampaikan kesaksian mereka. ${ }^{144}$ Seperti di negara lain, di Indonesia pengembangan teologi Roh Kudus yang utuh dan komprehensif secara nalariah dan teologis atau sistematika tidak menjadi fokus utama. Menurut beberapa ahli seperti Menzies, apa yang dibangun adalah pneumatologi eksperiensial. Artinya, pengalaman pribadi dan komunal menjadi dasar untuk memahami dan membahas serta, membangun teologi tentang Roh Kudus. Lebih tepat kalangan Pentakostal mengembangkan pemahaman tentang peran Roh Kudus yang dialami, dinikmati, dan dibagikan serta baru kemudian dirapihkan konsepnya dalam proses merespons percakapan teologis yang dilakukan pihak di luar mereka. Namun, keterbukaan mereka menjelaskan pengalaman spiritual mereka atau subjectivitas mereka cukup besar. Misalnya, respon Menzies pada Karkkainen. ${ }^{145}$

Kedua elemen di dalam kehidupan umat Kristen sedunia berkelindan. Dinamika yang ada di gerakan Pentakostal-Karismatis memberikan mereka pengakuan bahwa mereka adalah faktor yang signifikan dalam membuat Gereja berefleksi serius sesudah masa Reformasi di abad XVI. Kemungkinan sekali hal ini terjadi karena, penghayatan mereka akan gerak Roh Kudus yang fleksibel. Namun, bagaimanapun juga lambat laun muncul berbagai pemimpin mereka yang menangani perumusan Pneumatologi di kalangan ini seperti yang ditulis oleh Menzies ${ }^{146}$ atau Frank Macchia. ${ }^{147}$

Tidak dapat disangkal, sedikit banyak gerakan di atas ikut menimbulkan perhatian besar pada peran Roh Kudus dan membuat setiap kalangan Kristen menanggapi hal ini. Di

\footnotetext{
${ }^{143}$ Vinson Synan, The Century of the Holy Spirit: 100 Years of Pentecostal and Charismatic Renewal, 1901 2001 (Nashville, Tennnesse: Thomas Nelson, 2012), https://doi.org/10.1163/15700747-12341245. p. 13

${ }^{144}$ Ishak Sugianto, The Transforming Power Of the Holy Spirit: Membangkitkan Kembali Pelayanan Para Rasul Dalam Gereja Masa Kini (Yogyakarta: Andy Press, 2009).

145 Robert P. Menzies, "The Nature of Pentecostal Theology: A Response to Velli-Matti Kärkkäinen and Amos Yong," Journal of Pentecostal Theology, 2017, https://doi.org/10.1163/17455251-02602003.

146 Robert P. Menzies, The Development of Early Christian Pneumatology (Sheffield: Academic Prress, 1991).

${ }^{147}$ Frank Macchia, Baptized in the Spirit: Global Pentecostal Theology (Grand Rapids, MI, 2006).
} 
Gereja Roma Katolik, sesudah Konsili Vatikan ke-2 semakin jelas perhatian mereka, di kalangan Protestan terutama di kalangan Gerakan Ekumene yang berkelindan di sekitar kegiatan Dewan Gereja Sedunia (World Council of Churches) semakin banyak pemimpin Gereja dan teolog menyadari perlunya pendalaman mengenai Roh Kudus dan peran-Nya. Apalagi, seorang pemimpin dari Rusia menyatakan bahwa, perhatian pada Roh Kudus di gereja-gereja barat sangat lemah. Kebangkitan perhatian pada Pneumatologi terlihat nyata dalam pertemuan di Canberra pada tahun 1991 sesudah proses yang panjang. Percakapan ini dilanjutkan dalam pertemuan lainnya bahkan, yang dilakukan di Afrika sehingga diciptakan komite bersama antara kalangan Ekumene dan Karismatik. Sebelumnya terjadi juga komite bersama antara Gereja Orthodox dengan kalangan Ekumene. Perhatian pada Roh Kudus membuat juga perhatian ditujukan untuk mengkaji roh-roh yang ada di masyarakat dan di dalam hidup pribadi serta di dalam hidup kepercayaan rakyat lokal. Percakapan dan perdebatan terus berlangsung. ${ }^{148}$

Tulisan-tulisan pakar teologi dari Fuller Seminary termasuk Karkkainen menambah dorongan untuk mendalami pneumatologi lebih jauh. ${ }^{149}$ Sejak itu, berbagai aspek mengenai peran Roh Kudus menjadi perhatian besar. Di kalangan Gereja-gereja Injili berbagai respon juga muncul, John MacArthur dalam bukunya Strange Fire menyatakan dengan tajam bahwa, kalangan Injili bersalah karena mengabaikan Roh Kudus, namun di pihak lain, penulis ini menilai bahwa, mayoritas kalangan Karismatik mengajarkan Roh Kudus yang tidak sama dengan apa yang ada di Alkitab. ${ }^{150}$

Namun di tengah antusiasme yang meningkat, kaitan antara Roh Kudus dan Misi Allah tidak terlihat ketat di dalam Misiologi Gereja. Secara tradisional soteriologi dan Kristuslah yang menjadi fokus dari misiologi Kristen.

Di tengah proses itu, para pakar di kalangan arus utama semakin menekankan konsep Missio Dei yaitu, Misi Allah yang memberi kehidupan, memberdayakan manusia, menumbuhkannya, dan membebaskannya Missiologi mulai dikaitkan dengan konsep tersebut. Maka di dekade ini terjadi perubahan dalam konsep eklesiologi, missiologi, dan

\footnotetext{
${ }^{148}$ Veli Matti Kärkkäinen, Kirsteen Kim, and Amos Yong, Interdisciplinary and Religio-Cultural Discourses on a Spirit-Filled World: Loosing the Spirits, Interdisciplinary and Religio-Cultural Discourses on a Spirit-Filled World: Loosing the Spirits, 2013, https://doi.org/10.1057/9781137268990.

${ }^{149}$ Veli-Matti Karkkainen, Pneumatology: The Holy Spirit in Ecumenical, International, and Contextual Perspective., 2nd ed. (Grand Rapids, MI: Bakers Academic, 2018)., p. 5

150 John MacArthur, Strange Fire: The Danger of Offending the Holy Spirit with Counterfeit Worship (Nashville, Tennessee: Neslon, 2013), p. 5.
} 
Pneumatologi serta Kristologi, yang semuanya mulai terintegrasi dengan konsep Missio Dei menjadi suatu kerangka besar dan dalam Missio Dei, peranan Roh Kudus sejak awal segalanya ditekankan.

Namun, sejauh ini dalam rangka Missio Dei, kaitan antara corak kepemimpinan, misi Allah, dan pemahaman mengenai peran Roh Kudus di gereja sejauh penulis ketahui belum pernah diteliti di Indonesia dengan mendalam walaupun pembahasan mengenai hubungan Roh Kudus dan Misi Gereja banyak dipercakapkan. Misalnya, ada studi yang menghubungkan karunia Roh di jemaat dengan misi. ${ }^{151}$ Lebih lanjut, walaupun karya Lukas dalam Injil Lukas dan Kitab Kisah Rasul banyak mendapatkan perhatian para penulis, percakapan mengenai peran Roh Kudus di dalam misi membahas beberapa hal utama, namun ada suatu hal yang tidak banyak dibahas, khususnya dalam Kitab Kisah Rasul pasal 16 yang menggambarkan perjalanan Paulus yang kedua dan Peran Roh Kudus dalam mengubah cara kepemimpinnan.

Tulisan ini juga menemukan hal yang mungkin terluput diperhatikan dalam peran Roh Kudus untuk mengubah diri pemimpin-pemimpin yang dipanggil-Nya untuk melaksanakan Misi Allah. Roh Kudus ingin pemimpin-pemimpin yang telah disentuh-Nya lebih memaknai kehadiran-Nya dan kehendak-Nya secara bersama. Roh Kudus ingin juga para pemimpin berani melintasi atau menerobosi batas pandangan, etnisitas, kelas sosial, bahkan dualisme kafir dan beriman karena Misi Allah adalah harus berdampak di dunia dan Kerajaan Allah semakin kentara dan dialami sehingga orang mengalami hidup didalamnya. Hal ini harus dimulai dengan para pemimpin dibebaskan dari kungkungan pola pikir kepemimpinan dan pola kerja yang terikat roh-roh yang lama. Dengan demikian Missio Dei bukan hanya mengubah orang yang "belum menerima berita Injil" atau mengubah dunia, namun terutama dan juga mengubah para pelaksana misi Allah, yaitu para pemimpin di Gereja.

${ }^{151}$ Eben Munthe, "Mengoptimalkan Karunia Dalam Jemaat Untuk Melakukan Misi Amanat Agung Di Era 4.0," EPIGRAPHE: Jurnal Teologi Dan Pelayanan Kristiani, 2019, https://doi.org/10.33991/epigraphe.v3i2.127. 


\section{Implikasi dan saran bagi kepemimpinan gerejawi masa kini}

Beberapa implikasi dari penelaahan di atas bagi kehidupan kepemimpinan gerejawi dapat dipaparkan di bawah ini:

1. Di setiap masa kepemimpinan gerejawi harus memiliki kepekaan pada arah atau kehendak dari Roh Kudus. Di masa kini, dengan banyaknya berbagai perubahan dan tingkat kesibukan yang dihadapi para pemimpin gerejawi, sangat diperlukan kepekaan yang lebih dalam pada kehendak-Nya. Dengan demikian, para pemimpin perlu menjadikan pencarian atau penyimakan pada kehendak Allah sebagai prioritas dalam pelayanannya.

2. Sejalan dengan apa yang ditemukan dalam studi kepemimpinan di ranah yang bukan gerejawi, studi di atas menunjukkan bahwa, di Gereja yang melaksanakan misi Allah tekanan pada kepemimpinan kolektif atau shared leadership menjadi suatu hal yang harus dipelajari oleh berbagai Gereja yang sudah sangat terbiasa dengan kepemimpinan tunggal dan berkarisma serta memukau.

3. Kepemimpinan di dalam Kitab Kisah Rasul 16 menunjukkan kepemimpinan yang bersedia menjalani perubahan dengan keyakinan karena, keberhasilan menurut kacamata pemimpin belum tentu sesuai dengan rencana Roh Kudus dan Ia ternyata menyediakan banyak hal-hal besar dan indah di masa depan. Juga pemimpin perlu bersama berani menerobos dan keluar dari hal-hal yang membuatnya nyaman bila Roh Kudus mengarahkannya ke jurusan yang berbeda.

\section{Kesimpulan}

Kisah Para Rasul 16 memberikan pesan tersembunyi bahwa Roh Kudus adalah Ia yang berdaulat, merencana, dan mendidik serta menentukan arah dan waktu pekerjaan misi Allah. Roh Kudus memberikan hidup dan pemberdayaan serta pembebasan. Ia melibatkan sosok-sosok luar biasa seperti Paulus dan juga orang-orang biasa, namun inisiatif-Nya dan arah-Nya perlu dimaknai oleh para pemimpin pilihan-Nya bersama dengan seluruh anggota tim yang Ia pilih. Tanpa pelaksanaan misi seperti itu, maka rencana Tuhan justru dihalangi oleh anak-anak-Nya atau orang-orang yang menjadi pemimpin. Karena itu, di dalam penerapan misi untuk dunia modern, doa dari para pemimpin bagi dirinya adalah "Berikan daku rasa aman ketika banyak halangan terjadi 
di dalam pelayanan misi Allah yang diemban ...jangan biarkan rasa takut gagal menguasai aku."

Selanjutnya peran pemimpin adalah membuka ruang dalam rohnya agar semakin menyatu dengan Roh Kudus dalam berbagai peran-Nya yaitu antara lain,
a. Menyampaikan berita tentang Tuhan Yesus
b. Mendemonstrasikan kuasa Kristus hadir
c. Mengajar atau mengubah orang
d. Mendoakan
e. Memulihkan dan membebaskan orang dari ketakutan dan berbagai derita
f. Mengorganisir, dan mendelegasi, dsb, seperti yang dilakukan oleh Paulus dan teman-temannya.

Studi lebih lanjut tentu masih diperlukan untuk menentukan halangan para pemimpin di Asia Tenggara yang sepintas lalu kentara nyaman berperan sebagai pemimpin yang tunggal dan bukan kepemimpinan bersama seperti yang dilakukan oleh para Rasul. Prakiraan yang dapat dilontarkan adalah peran dan kuasa roh-roh budaya setempat yang menekankan kepemimpinan yang hierarkis, paternalistis, otoriter, dan karismatis lebih nyata dan dipegang daripada kepemimpinan yang berpusat pada Roh Kudus.

Kemungkinan lain adalah perubahan cepat dalam tiga dasawarsa terakhir membuat banyak pemimpin merasa tidak tenang dan aman dalam transisi dan perubahan nonstop. Sementara melalui budaya teknologi digital, orang-orang yang dipimpin semakin terbiasa dengan eksplorasi mandiri, kolaborasi lintas batas, dan ekspresi yang otentik.

\section{Daftar Pustaka}

Barth, Hans-Martin. The Theology of Martin Luther. The Theology of Martin Luther, 2018. https://doi.org/10.2307/j.ctt22nm8rj.

Camery-Hoggatt, Jerry. "George K. A. Bonnah, The Holy Spirit: A Narrative Factor in the Acts of the Apostles." Pneuma 32, no. 3 (November 12, 2010): 438-39. https://doi.org/10.1163/157007410x533996.

Chan, Francis. Forgotten God: Reversing Our Tragic Neglect of the Holy Spirit. Colorado Springs, CO: David C Cook, 2009. 
Clandinin, D. Handbook of Narrative Inquiry: Mapping a Methodology. Jossey-Bass. San-Francisco, 2012. https://doi.org/10.4135/9781452226552.

Clandinin, D. Jean. Engaging in Narrative Inquiry. Engaging in Narrative Inquiry. 2nd ed. New York: Routledge, 2016. https://doi.org/10.4324/9781315429618.

Crimella, Matteo. “The Vision of the Macedonian: Acts 16:6-10." Revue Biblique 2014. Accessed August 30, 2020.

https://www.academia.edu/39374935/The_Vision_of_the_Macedonian_Acts_16_6_10.

Donlon, Christopher. "Luke's Pneumatological Eschatology: Theological Motifs in Luke-Acts." South Eastern University, 2012. https://www.academia.edu/2536151/Lukes_Pneumatological_Eschatology_Theological_M otifs_in_Luke_Acts.

Evans, Jimmie. "The Third Person of the Trinity: How the Holy Spirit Facilitates Man's Walk with God." Fidei et Veritatis: The Liberty University Journal of Graduate Research 1, no. 1 (January 20, 2016). https://digitalcommons.liberty.edu/fidei_et_veritatis/vol1/iss1/8.

Fry, Ronald E. Appreciative Inquiry and Organizational Transformation: Reports from the Field. Westport, CB: Quorum Books, 2002.

Hoon, Chang-Yau. "2. Pentecostal Megachurches in Jakarta: Class, Local, and Global Dynamics." In Pentecostal Megachurches in Southeast Asia, 21-46. ISEAS-Yusof Ishak Institute Singapore, 2019. https://doi.org/10.1355/9789814786898-005.

Karkkainen, Veli-Matti. Pneumatology: The Holy Spirit in Ecumenical, International, and Contextual Perspective. 2nd ed. Grand Rapids, MI: Bakers Academic, 2018.

- - - "The Ecumenical Potential of Pneumatology." Gregorianum 80, no. 1 (1999): 121-45. https://www.jstor.org/stable/23580447?seq=1.

Kärkkäinen, Veli Matti. "Mission in Pentecostal Theology." International Review of Mission 107, no. 1 (June 1, 2018): 5-22. https://doi.org/10.1111/irom.12205.

Kärkkäinen, Veli Matti, Kirsteen Kim, and Amos Yong. Interdisciplinary and Religio-Cultural Discourses on a Spirit-Filled World: Loosing the Spirits. Interdisciplinary and Religio-Cultural Discourses on a Spirit-Filled World: Loosing the Spirits, 2013. https://doi.org/10.1057/9781137268990.

Lee, Chang-Soung. "Who Is the Father of Pentecostal Movement?" Journal of Youngsan Theology, 2018. https://doi.org/10.18804/jyt.2018.03.43.303.

MacArthur, John. Strange Fire: The Danger of Offending the Holy Spirit with Counterfeit Worship. Nashville, Tennessee: Neslon, 2013.

Macchia, Frank. Baptized in the Spirit: Global Pentecostal Theology. Grand Rapids, MI, 2006.

Martins, Helena. "Novel Metaphor and Conceptual Stability." In DELTA Documentacao de Estudos Em Linguistica Teorica e Aplicada, 2006. https://doi.org/10.1590/s010244502006000300010.

Menzies, Robert P. The Development of Early Christian Pneumatology. Sheffield: Academic Prress, 1991. 
- - C. "The Nature of Pentecostal Theology: A Response to Velli-Matti Kärkkäinen and Amos Yong." Journal of Pentecostal Theology, 2017. https://doi.org/10.1163/1745525102602003.

Moltmann, Jürgen. The Spirit of Life: A Universal Affirmation. Minneapolis, Minnessota: Fortress Press, 2001.

Munthe, Eben. "Mengoptimalkan Karunia Dalam Jemaat Untuk Melakukan Misi Amanat Agung Di Era 4.0." EPIGRAPHE: Jurnal Teologi Dan Pelayanan Kristiani, 2019. https://doi.org/10.33991/epigraphe.v3i2.127.

Niemandt, Cornelius Johannes Petrus. "Discerning Spirituality for Missional Leaders." In Contributions to Management Science, 151-68, 2019. https://doi.org/10.1007/978-3-31998884-9_10.

Peterson, David. "Additional Note: The Meaning and Application of the Council Narrative." In The Acts of the Apostles, 442-446. Grand Rapids, Mich: Willliam Eerdsmans Pub, 2009.

"Pneumatology: The Holy Spirit in Ecumenical, International, and Contextual Perspective." Choice Reviews Online 40, no. 04 (2002). https://doi.org/10.5860/choice.40-2114.

"Pneumatology: The Holy Spirit in Ecumenical, International, and Contextual Perspective." Choice Reviews Online 40, no. 04 (December 1, 2002): 40-2114-40-2114. https://doi.org/10.5860/choice.40-2114.

Reissman, Catherine. Narrative Analysis. Newbury Park, California: Sage, 1993.

Roebuck, David G. "Vinson Synan \& Charles R. Fox, Jr., William J. Seymour: Pioneer of the Azusa Street Revival (Alachua, FL: Bridge-Logos, 2012). 355 Pp., \$16.99 Paperback." Pneuma 35, no. 1 (2013). https://doi.org/10.1163/15700747-12341299.

Sirks, G. J. "The Cinderella of Theology: The Doctrine of the Holy Spirit." Harvard Theological Review 50, no. 2 (1957): 77-89. https://doi.org/10.1017/S001781600002842X.

Soh, Seng Chai Desmond. "The Holy Spirit and Missions." In Holy Spirit: Unfinished Agenda, 2628, 2014. https://www.academia.edu/35006499/Holy_Spirit_Unfinished_Agenda.

Sugianto, Ishak. The Transforming Power Of the Holy Spirit: Membangkitkan Kembali Pelayanan Para Rasul Dalam Gereja Masa Kini. Yogyakarta: Andy Press, 2009.

Supatra, Hendarto. “Mengenal Pentakostalisme Di Indonesia." Jurnal Abdiel 3, no. 2 (November 22, 2019): 11-24. https://doi.org/10.37368/ja.v3i2.97.

Synan, Vinson. The Century of the Holy Spirit: 100 Years of Pentecostal and Charismatic Renewal, 1901-2001. Nashville, Tennnesse: Thomas Nelson, 2012. https://doi.org/10.1163/15700747-12341245.

Thahn, Nguyen Van. "God and The Gentile Mission: A Lukan Theological and Missiological Agenda." Sapientia Logos 5, no. 2 (2013): 1-31. https://www.academia.edu/4182827/God_and_the_Gentile_Mission_A_Lukan_Theological _and_Missiological_Agenda.

Thiselton, Anthony. The Holy Spirit: In Biblical Teaching, through the Centuries and Today. Grand Rapids: Michigan: Eerdmans, 2013. 
Zimmerling, Peter. "Pneumatology." In The Routledge Companion to Modern Christian Thought, 2013. https://doi.org/10.4324/9780203387856.

Tentang Penulis:

Pdt. Em. Dr. Robby I. Chandra adalah staf pengajar di STT Cipanas, Jawa Barat dan pendeta emeritus di GKI Kayuputih, Jakarta. Beliau juga aktif di berbagai lembaga, di antaranya sebagai salah seorang inisiator Food Terminal di Jakarta. Email: robbycha@yahoo.com 